\title{
Effect of Gibberellic Acid and Pachlobutrazol Spraying on Fruit Characteristics of Williams Banana under Assuit Conditions \\ Khodair, O. A. ${ }^{1}$ and E. M. A. Radwan ${ }^{2}$ \\ ${ }^{1}$ Horticultural Dept. Fac.Agric.Al Azhar University, Assiut, Egypt. \\ ${ }^{2}$ Horticultural Dept., Fac. Agric. The New Valley University, Egypt. \\ Corresponding author: essamabdelzaher669@aun.edu.eg
}

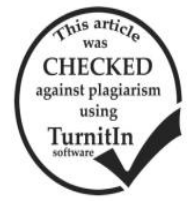

\section{ABSTRACT}

This study was carried out during two consecutive seasons of 2016/2017 and 2017/2018 on the third and fourth ratoons of Williams banana plants. The plants were grown in the experimental orchard of Al Azhar University., Assiut Governorate., Egypt. The experiment was set up in a split plot arrangement design. Bunches were sprayed twice (just after emergence of the last hand and one month later and thrice) with gibberellic acid $\left(\mathrm{GA}_{3}\right)$ and Aug. at a rate of $40 \mathrm{ppm}$ Pachlobutrazol $(\mathrm{PB})$ sprayed at rates of $2 \mathrm{~g}$ and $4 \mathrm{~g} / \mathrm{L}$ at Aug.The obtained results revealed that spraying $\left(\mathrm{GA}_{3}\right)$ and pachlobutrazol $(\mathrm{PB})$ led to increase bunch and finger weights the fruit characteristics There was an improvement of chemical fruit constituents in term of increasing total soluble solids (TSS \%), sugars contents and decreasing the total acidity percentages due to spray of $\mathrm{GA}_{3}$ or pachlobutrazol (PB) singly or interaction of them compared to the control treatment. Then, it could be concluded that spraying $40 \mathrm{ppm} \mathrm{GA}$ thrice. As well as spraying pachlobutrazol (PB) at $(2 \mathrm{~g}) / \mathrm{L}$ seems to be the promising treatment under this experiment conditions to get the best results with regard to yield and fruit quality.

Keywords: Williams Banana, gibberellic acid, pachlobutrazol, yield, fruit quality.

\section{INTRODUCTION}

Banana (Musa spp) is one of the major commercial fruit crops grown in tropics, subtropics and plays a key role in the economy of farmers. It cultivated over 130 countries in the tropical and subtropical regions and the fourth largest fruit crop in the world, following grapes, citrus and apple. It plays an important role in tropical economics as cash export and as complementary food in local sets. Bananas have a great economic importance as one of the most popular fruits in Egypt for its high nutritive value, cheap source of energy i.e. high starch content vitamins and other minerals with traces of fat (Abdel-Moniem et al., 2008). The total area of banana increased to 65790 feddan producing 1341478 tons with an average value of 20.39 ton/ feddan according to FAOSTAT (2016).

Williams Banana has many features, i.e., large bunch with longer fingers and the excellent taste. It owing to its large size and rapid growth rate require relatively large amount of nutrients to maintain high production of good quality fruits (Saleh, 2001). So, the gibberellins are especially abundant in seeds and young shoots where they control stem elongation by stimulating both cell division and elongation (Moore, 1979). Many investigators studied the effect of $\mathrm{GA}_{3}$ sprays on banana bunches after emergence and found a great effect on bunch weight and fruit quality. Tadros, et al (1984), Chattopadhyay, and Jana, (1988), Dinesh Kumar and Reddy, (1998), Pradhan et al, (1988), Hemeed, (2006) and Ebeed. Sanna., et al (2008).

The aim of this study was to elucidating the effect of different concentrations and frequencies of gibberellic acid and pachlobutrazol sprays on fruit characteristics, yield and fruit quality of Williams banana grown under Assuit climatic conditions.

\section{MATERIALS AND METHODS}

This study was carried out during two consecutive seasons of 2016/2017 and 2017/2018 seasons on the third and fourth ratoons of Williams banana plants. The plants are grown in experimental orchard of Alazher University., Assiut Governorate., where the soil has a clay texture with a water table depth not less than two meters .The plants were spaced at $3.5 \times 3.5$ meters apart. All plants were similar in age, growth and received the recommended agricultural practices, the fertilization program and the other agricultural practices were the same for all plants under investigation.

The experiment involved two studied factors (A\&B). The first factor (A) included the factor of gibberellic acid that involved three treatments as follow:

1. Control treatment (spraying water only).

2. Spraying twice $\mathrm{GA}_{3}$ at a rate of $40 \mathrm{ppm}\left(2^{\text {nd }}\right.$ week of Mar. and Apr.).

3. Spraying $\mathrm{GA}_{3}$ at a rate of $40 \mathrm{ppm}$ thrice $\left(1^{\text {st }}\right.$ week of Aug.).

$\mathrm{GA}_{3}$ was used at $40 \mathrm{ppm}$ as spraying treatments twice sprays on the emerged bunches (just after emergence of the last hand and one month later); then repeated on $1^{\text {st }}$ week of August.

The second factor (B) involved three treatments of pachlobutrazol spraying as follow:

1. Control treatment (spray water only).

2. Spraying pachlobutrazol $(\mathrm{PB})$ at a rate of $(2 \mathrm{~g}) / \mathrm{L}$

3. Spraying pachlobutrazol (PB) at a rate of $(4 \mathrm{~g}) / \mathrm{L}$

Pachlobutrazol (PB) was sprayed once on the emerged bunches on the first week $1^{\text {st }}$ of August.

The experiment was set up as split plot arrangement complete randomized block design, each treatment was replicated five times, one stool per each. At the harvest stage (when the fingers reached full stage), bunches were harvested and the following determinations were performed for each plant:

- Average bunch weight in $\mathrm{kg}$.

- Average finger weight in gm.

- Finger length in $\mathrm{cm}$.

- Finger diameter in $\mathrm{cm}$.

- Pulp/ finger weight ratio.

- Total soluble solids percentage in the pulp.

- Total acidity percentage (as malic acid) in the pulp.

- Reducing sugars percentage in the pulp.

- Total sugars percentage in the pulp.

All chemical determinations were performed following the description of A.O.A.C. methods (1995). All the obtained data were tabulated and statistically analyzed. The differences between various treatment means were compared using L.S.D. test at 5\% according to Gomez and Gomez (1984) and Mead et al. (1993). 


\section{RESULTS}

1- Bunch and physical fruit traits

In general view data in Tables (1to5) showed the effect of gibberellic acid $\left(\mathrm{GA}_{3}\right)$ and pachlobutrazol $(\mathrm{PB})$ and interaction between them on bunch and physical finger traits of Williams banana plants during 2016/2017 and 2017/2018 growing seasons. It is obvious from data that the results took similar trend during the two studied seasons.

Concerning the effect of $\mathrm{GA}_{3}$ spraying, the results indicated that there was a gradual significantly increment of bunch weight and finger, pulp $\%$ and dimensions of fingers due to increasing the spraying from zero to three times.

No significant differences were obtained between the treatments due to the raise of spraying number from twice to thrice. The recorded bunch weight was $(25.15,27.97 \& 28.24$ $\mathrm{kg}$ ) and $(25.59,28.41$ and $28.33 \mathrm{Kg})$, as well as the finger weight was $(90.74,100.55 \& 99.96 \mathrm{gm}$.) and (93.50, 103.77and 103.74 gm.) due to $\mathrm{GA}_{3}$ spray null, twice and thrice during the two studied seasons, respectively.
Thus, the increment percentage of bunch weight due to $\mathrm{GA}_{3}$ spraying over unsprayed attained $(11.21 \& 12.29 \%)$ and $(11.02 \& 10.71 \%)$ due to $\mathrm{GA}_{3}$, twice and thrice during the two studied seasons, respectively. The corresponding increment percentage of finger weight was attained (10.81\&10.16) and (10.98\&10.95), respectively.

These effects are very important in banana production since the increasing of the bunch and finger weights is the most important target due to induce an increase the packable yield and their price.

As regard to effect of pachlobutrozol spraying, data indicated that all treatment no significantly difference in these studied bunch and finger traits due to spraying pachlobutrazol (PB) at any concentration whatever,2 or 4 $\mathrm{g} /$ stool compared to unsprayed ones (control).

In addition data presented in tables (1 to 5) indicated that the interaction between the two studied factors $\left(\mathrm{GA}_{3} \&\right.$ $\mathrm{PB})$ these results showed that the same effect as spray $\mathrm{GA}_{3}$ only, whereas PB spraying does not effect of these studied traits. Thus the effects due to spray $\mathrm{GA}_{3}$ only.

Table 1. Effect of $\mathrm{GA}_{3}$ and pachlobutrazol spraying on Bunch weight (Kg) of Williams banana during 2016/2017 and $2017 / 2018$ seasons.

\begin{tabular}{|c|c|c|c|c|c|c|c|c|}
\hline \multirow{2}{*}{$\begin{array}{l}\text { Season } \\
\text { Treatment }\end{array}$} & \multicolumn{4}{|c|}{$2017 / 2016$} & \multicolumn{4}{|c|}{ 2018/2017 } \\
\hline & Zero & (Twice GA GA $_{3}$ & (thrice GA $\left.\mathbf{G A}_{3}\right)$ & Mean(B) & Zero & (Twice GA $\mathbf{A}_{3}$ ) & (thrice $\mathbf{G A}_{3}$ ) & Mean(B) \\
\hline Control & 24.86 & 27.50 & 27.82 & 26.73 & 25.26 & 27.98 & 28.28 & 27.17 \\
\hline $\mathrm{PB}(2 \mathrm{~g})$ & 25.38 & 28.21 & 28.53 & 27.37 & 25.78 & 28.63 & 28.93 & 27.78 \\
\hline $\mathrm{PB}(4 \mathrm{~g})$ & 25.22 & 28.19 & 28.37 & 27.26 & 25.73 & 28.61 & 28.89 & 27.71 \\
\hline Mean (A) & 25.15 & 27.97 & 28.24 & & 25.59 & 28.41 & 28.33 & \\
\hline L.S.D 5\% & & $\begin{array}{c}\mathrm{A}= \\
\mathrm{B}= \\
\mathrm{AB}\end{array}$ & $\begin{array}{l}1.41 \\
\text { N.S } \\
2.62\end{array}$ & & & $\begin{array}{c}\mathrm{A}=1 \\
\mathrm{~B}= \\
\mathrm{AB}=\end{array}$ & $\begin{array}{l}1.49 \\
\text { N.S } \\
2.70\end{array}$ & \\
\hline
\end{tabular}

Table 2. Effect of $\mathrm{GA}_{3}$ and pachlobutrazol spraying on finger weight (g) of Williams banana during 2016/2017 and 2017/2018 seasons.

\begin{tabular}{|c|c|c|c|c|c|c|c|c|}
\hline \multirow{2}{*}{$\begin{array}{l}\text { Season } \\
\text { Treatment }\end{array}$} & \multicolumn{4}{|c|}{$2017 / 2016$} & \multicolumn{4}{|c|}{ 2018/2017 } \\
\hline & Zero & (Twice GA $\mathbf{G}_{3}$ & (thrice GA $\left.\mathbf{G A}_{3}\right)$ & Mean(B) & Zero & (Twice $\mathbf{G A}_{3}$ ) & (thrice $\mathbf{G A}_{3}$ ) & $\overline{M e a n}(\mathbf{B})$ \\
\hline Control & 89.83 & 98.87 & 98.39 & 95.70 & 92.36 & 102.08 & 101.96 & 98.80 \\
\hline $\mathrm{PB}(2 \mathrm{~g})$ & 91.42 & 101.38 & 101.14 & 97.98 & 94.45 & 104.88 & 105.01 & 101.60 \\
\hline $\mathrm{PB}(4 \mathrm{~g})$ & 90.96 & 101.39 & 100.34 & 97.56 & 93.69 & 104.36 & 104.26 & 100.77 \\
\hline Mean (A) & 90.74 & 100.55 & 99.96 & & 93.50 & 103.77 & 103.74 & \\
\hline L.S.D 5\% & & $\begin{array}{c}\mathrm{A}= \\
\mathrm{B}= \\
\mathrm{AB}\end{array}$ & $\begin{aligned} & 4.07 \\
= & \mathrm{N} . \mathrm{S} \\
= & 4.16\end{aligned}$ & & & $\begin{array}{r}\mathrm{A}= \\
\mathrm{B}= \\
\mathrm{AB}\end{array}$ & $\begin{aligned} & 3.68 \\
= & \mathrm{N} . \mathrm{S} \\
= & 5.22\end{aligned}$ & \\
\hline
\end{tabular}

Table 3. Effect of $\mathrm{GA}_{3}$ and pachlobutrazol spraying on Pulp (\%) of Williams banana during 2016/2017 and 2017/2018 seasons.

\begin{tabular}{|c|c|c|c|c|c|c|c|c|}
\hline \multirow{2}{*}{$\begin{array}{l}\text { Season } \\
\text { Treatment }\end{array}$} & \multicolumn{4}{|c|}{$2016 / 2017$} & \multicolumn{4}{|c|}{$2017 / 2018$} \\
\hline & Zero & (Twice GA $\mathbf{A}_{3}$ ) & (thrice $\mathbf{G A}_{3}$ ) & Mean(B) & Zero & (Twice GA $\left.\mathbf{A A}_{3}\right)$ & (thrice $\mathbf{G A}_{3}$ ) & Mean(B) \\
\hline Control & 59.18 & 64.80 & 65.07 & 63.01 & 59.77 & 64.03 & 64.60 & 62.80 \\
\hline $\mathrm{PB}(2 \mathrm{~g})$ & 60.60 & 63.71 & 66.62 & 63.65 & 61.66 & 63.92 & 64.91 & 63.30 \\
\hline $\mathrm{PB}(4 \mathrm{~g})$ & 60.53 & 64.48 & 64.76 & 63.26 & 60.69 & 64.84 & 65.72 & 63.95 \\
\hline $\operatorname{Mean}(\mathrm{A})$ & 60.10 & 64.33 & 65.48 & & 60.71 & 64.26 & 65.08 & \\
\hline \multirow{3}{*}{ L.S.D 5\% } & \multicolumn{4}{|c|}{$\mathrm{A}=2.78$} & \multicolumn{4}{|c|}{$\mathrm{A}=2.61$} \\
\hline & \multicolumn{4}{|c|}{$\mathrm{B}=\mathrm{N} . \mathrm{S}$} & \multicolumn{4}{|c|}{$\mathrm{B}=\mathrm{N} . \mathrm{S}$} \\
\hline & \multicolumn{4}{|c|}{$\mathrm{AB}=4.73$} & \multicolumn{4}{|c|}{$\mathrm{AB}=4.39$} \\
\hline
\end{tabular}

Table 4. Effect of $\mathrm{GA}_{3}$ and pachlobutrazol spraying on finger length (cm) of Williams banana during 2016/2017 and 2017/2018 seasons.

\begin{tabular}{|c|c|c|c|c|c|c|c|c|}
\hline \multirow{2}{*}{$\begin{array}{l}\text { Season } \\
\text { Treatment }\end{array}$} & \multicolumn{4}{|c|}{$2017 / 2016$} & \multicolumn{4}{|c|}{$2018 / 2017$} \\
\hline & Zero & (Twice $\mathbf{G A}_{3}$ ) & (thrice $\left.\mathbf{G A}_{3}\right)$ & Mean(B) & Zero & (Twice GA, & (thrice $\mathbf{G A}_{3}$ ) & Mean(B) \\
\hline Control & 22.54 & 23.98 & 24.09 & 23.54 & 22.66 & 24.58 & 23.30 & 23.51 \\
\hline $\mathrm{PB}(2 \mathrm{~g})$ & 22.64 & 24.10 & 24.23 & 23.66 & 23.13 & 24.67 & 24.50 & 24.10 \\
\hline $\mathrm{PB}(4 \mathrm{~g})$ & 22.44 & 23.96 & 24.66 & 23.69 & 23.10 & 24.83 & 24.54 & 24.17 \\
\hline $\operatorname{Mean}(\mathrm{A})$ & 22.54 & 24.01 & 24.33 & & 22.96 & 24.69 & 24.45 & \\
\hline L.S.D 5\% & & $\begin{array}{c}\mathrm{A}= \\
\mathrm{B} \\
\mathrm{AB}\end{array}$ & $\begin{aligned} & 0.83 \\
= & \text { N.S } \\
= & 1.43\end{aligned}$ & & \multicolumn{3}{|c|}{$\begin{array}{l}\mathrm{B}=\mathrm{N} . \mathrm{S} \\
\mathrm{AB}=137\end{array}$} & \\
\hline
\end{tabular}


Table 5. Effect of $\mathrm{GA}_{3}$ and pachlobutrazol spraying on finger diameter (cm) of Williams banana during 2016/2017 and 2017/2018 seasons.

\begin{tabular}{|c|c|c|c|c|c|c|c|c|}
\hline \multirow{2}{*}{$\begin{array}{l}\text { Season } \\
\text { Treatment }\end{array}$} & \multicolumn{4}{|c|}{ 2016/2017 } & \multicolumn{4}{|c|}{$2017 / 2018$} \\
\hline & Zero & $\left(\right.$ Twice $\left._{\mathbf{G A}} \mathbf{3}_{3}\right)$ & $\left(\right.$ thrice $\left.\mathbf{G A}_{3}\right)$ & Mean(B) & Zero & $\left(\right.$ Twice $\left.\mathbf{G A}_{3}\right)$ & (thrice $\mathbf{G A}_{3}$ ) & Mean(B) \\
\hline Control & 3.29 & 3.55 & 3.52 & 3.45 & 3.35 & 3.54 & 3.57 & 3.49 \\
\hline $\mathrm{PB}(2 \mathrm{~g})$ & 3.46 & 3.63 & 3.56 & 3.53 & 3.43 & 3.65 & 3.65 & 3.55 \\
\hline $\mathrm{PB}(4 \mathrm{~g})$ & 3.42 & 3.60 & 3.56 & 3.53 & 3.50 & 3.72 & 3.64 & 3.62 \\
\hline $\operatorname{Mean}(\mathrm{A})$ & 3.39 & 3.59 & 3.53 & & 3.43 & 3.64 & 3.59 & \\
\hline L.S.D $5 \%$ & & $\begin{array}{c}\mathrm{A}= \\
\mathrm{B}= \\
\mathrm{AB}\end{array}$ & $\begin{array}{l}0.11 \\
\text { N.S } \\
0.19\end{array}$ & & & & $\begin{array}{l}=0.10 \\
=\mathrm{N} . \mathrm{S} \\
=0.17\end{array}$ & \\
\hline
\end{tabular}

\section{2- Chemical constituents}

It is clear from the data presented in Tables (6 to9) that there were improvements of chemical fruit constituents in term of increasing total soluble solids (TSS \%), sugars contents and decreasing the total acidity percentages due to spray of $\mathrm{GA}_{3}$ or pachlobutrazol (PB) singly or combined of them compared to the control treatment. Moreover, the improvement occurred due to interaction effects was more effective due to singly spraying whatever, $\mathrm{GA}_{3}$ or pachlobutrazol.

Concerning the effect of $\mathrm{GA}_{3}$, the obtained results shows that total soluble solids (TSS \%), sugars contents were significantly increased with $\mathrm{GA}_{3}$ treatment. There was a positive correlation between the numbers of $\mathrm{GA}_{3}$ spraying and improved the fruit constituents, where the highest values of TSS \% and sugars contents was recorded as a result of spraying three times. In addition, there was insignificant difference in these traits due to spraying $\mathrm{GA}_{3}$ twice compared to unsprayed ones. , the recorded TSS\% was $(18.64,18.43 \& 19.96 \%)$ and $(18.78,19.19 \& 20.32 \%)$ due to unsprayed $\mathrm{GA}_{3}$, twice and thrice during the two studied seasons, respectively.

Then the increment percentage attained (7.08, $7.56 \%$ ) due to $\mathrm{GA}_{3}$ spray three times compared to the unsprayed ones during the two studied seasons, respectively. In regarded to the effect of pachlobutrazol (PB), data showed that total soluble solids (TSS \%) and sugars contents were significantly increased due to spray of PB2 compared to unsprayed ones.no significant differences were observed due to rise the PB2 concentration spraying from 2 to $4 \mathrm{~g}$. The average TSS\% was $(18.94,20.90 \&$ $21.25 \%)$ and $(18.36,20.06 \& 19.87 \%)$ due to pachlobutrazol (PB), spray at 2 and $4 \mathrm{~g}$ during the two studied seasons, respectively.

Hence the corresponding increment percentage attained to $(10.35,12.20 \%)$ and $(9.26,8.22 \%)$, respectively on other hand, the total acidity took an opposite trend of total soluble solids effects.

Moreover data in presented in tables (6 to9) indicated that the chemical fruit properties significantly responded to interaction between $\mathrm{GA}_{3}$ and pachlobutrazol (PB) spraying.

All combination of sprayed thrice with pachlobutrazol (PB), spray at 2 and $4 \mathrm{~g}$ significantly increased the total soluble solids (TSS \%) and sugars contents compared other combination. On other hand such combination significantly decreased the total acidity. The maximum valves of total soluble solids (TSS \%) were (20.36\& 20.68\%) and (20.86\& 20.92\%) due to spraying $\mathrm{GA}_{3}$ thrice and spraying pachlobutrazol (PB) at 2 or $4 \mathrm{~g}$ against (17.27\& $17.80 \%$ ) due to unsprayed ones. During the two studied seasons, respectively. Hence the corresponding increment percentage attained (17.89\& $19.75 \%)$ and $(17.19 \& 19.53 \%)$ respectively. In general over seen their results declared that the improvement occurred due to interaction effects was more effective of singly treatment, compared to the single use of $\mathrm{GA}_{3}$ or pachlobutrazol (PB).

Table 6. Effect of $\mathrm{GA}_{3}$ and pachlobutrazol spraying on T.S.S. \% of Williams banana during 2016/2017 and 2017/2018 seasons.

\begin{tabular}{|c|c|c|c|c|c|c|c|c|}
\hline \multirow{2}{*}{$\begin{array}{l}\text { Season } \\
\text { Treatment }\end{array}$} & \multicolumn{4}{|c|}{ 2016/2017 } & \multicolumn{4}{|c|}{$2017 / 2018$} \\
\hline & Zero & (Twice $\mathbf{G A}_{3}$ ) & (thrice $\mathbf{G A}_{3}$ ) & Mean(B) & Zero & $\left(\right.$ Twice $\left.\mathbf{G A}_{3}\right)$ & (thrice $\left.\mathbf{G A}_{3}\right)$ & Mean(B) \\
\hline Control & 17.27 & 16.95 & 18.84 & 18.94 & 17.80 & 18.11 & 19.18 & 18.36 \\
\hline $\mathrm{PB}(2 \mathrm{~g})$ & 19.23 & 18.96 & 20.36 & 20.90 & 19.35 & 19.96 & 20.86 & 20.06 \\
\hline PB(4g) & 19.43 & 19.38 & 20.68 & 21.25 & 19.20 & 19.50 & 20.92 & 19.87 \\
\hline Mean (A) & 18.64 & 18.43 & 19.96 & & 18.78 & 19.19 & 20.32 & \\
\hline L.S.D 5\% & & $\begin{array}{l}\mathrm{A}= \\
\mathrm{B}= \\
\mathrm{AB}=\end{array}$ & $\begin{array}{l}0.51 \\
0.64 \\
1.11\end{array}$ & & & $\begin{array}{c}\mathrm{A}= \\
\mathrm{B}= \\
\mathrm{AB}=\end{array}$ & $\begin{array}{l}0.48 \\
0.56 \\
0.97\end{array}$ & \\
\hline
\end{tabular}

Table 7. Effect of $\mathrm{GA}_{3}$ and pachlobutrazol spraying on Total Sugars of Williams banana during $2016 / 2017$ and 2017/2018 seasons.

\begin{tabular}{|c|c|c|c|c|c|c|c|c|}
\hline \multirow{2}{*}{$\begin{array}{l}\text { Season } \\
\text { Treatment }\end{array}$} & \multicolumn{4}{|c|}{$2017 / 2016$} & \multicolumn{4}{|c|}{ 2018/2017 } \\
\hline & Zero & (Twice GA $\left.\mathbf{A}_{3}\right)$ & (thrice $\left.\mathbf{G A}_{3}\right)$ & Mean(B) & Zero & (Twice GA $\left.\mathbf{A}_{3}\right)$ & (thrice $\mathbf{G A}_{3}$ ) & Mean(B) \\
\hline Control & 15.26 & 14.95 & 16.62 & 15.61 & 15.70 & 15.97 & 16.91 & 16.19 \\
\hline $\mathrm{PB}(2 \mathrm{~g})$ & 16.97 & 16.72 & 17.96 & 17.22 & 17.07 & 17.60 & 18.39 & 17.69 \\
\hline $\mathrm{PB}(4 \mathrm{~g})$ & 17.14 & 17.09 & 18.24 & 17.49 & 16.93 & 17.20 & 18.45 & 17.53 \\
\hline Mean (A) & 16.45 & 16.25 & 17.61 & & 16.57 & 16.93 & 17.92 & \\
\hline L.S.D 5\% & & $\begin{array}{l}\mathrm{A}= \\
\mathrm{B}= \\
\mathrm{AB}=\end{array}$ & $\begin{array}{l}0.57 \\
0.62 \\
1.07 \\
\end{array}$ & & & $\begin{array}{c}\mathrm{A}= \\
\mathrm{B}= \\
\mathrm{AB}\end{array}$ & $\begin{array}{l}0.58 \\
.63 \\
1.09 \\
\end{array}$ & \\
\hline
\end{tabular}


Table 8. Effect of $\mathrm{GA}_{3}$ and pachlobutrazol spraying on Reducing of Williams banana during 2016/2017 and 2017/2018 seasons.

\begin{tabular}{|c|c|c|c|c|c|c|c|c|}
\hline \multirow{2}{*}{$\begin{array}{l}\text { Season } \\
\text { Treatment }\end{array}$} & \multicolumn{4}{|c|}{$2017 / 2016$} & \multicolumn{4}{|c|}{$2018 / 2017$} \\
\hline & Zero & (Twice $\mathbf{G A}_{3}$ ) & (thrice $\left.\mathbf{G A}_{3}\right)$ & Mean(B) & Zero & $\left(\text { Twice }_{\text {GA }}\right)_{3}$ & (thrice $\mathbf{G A}_{3}$ ) & $\operatorname{Mean}(B)$ \\
\hline Control & 6.75 & 7.78 & 7.48 & 7.00 & 7.06 & 7.29 & 7.63 & 7.33 \\
\hline $\mathrm{PB}(2 \mathrm{~g})$ & 7.53 & 7.74 & 8.12 & 7.80 & 7.72 & 8.09 & 8.39 & 8.07 \\
\hline PB(4g) & 7.90 & 7.90 & 8.25 & 7.95 & 7.75 & 7.88 & 8.38 & 8.00 \\
\hline Mean (A) & 7.33 & 7.47 & 7.95 & & 7.51 & 7.75 & 8.13 & \\
\hline L.S.D 5\% & \multicolumn{4}{|c|}{$\begin{array}{l}A=0.28 \\
B=0.24 \\
A B=0.41\end{array}$} & \multicolumn{4}{|c|}{$\begin{array}{l}\mathrm{A}=0.26 \\
\mathrm{~B}=0.25 \\
\mathrm{AB}=0.44\end{array}$} \\
\hline
\end{tabular}

Table 9. Effect of $\mathrm{GA}_{3}$ and pachlobutrazol spraying on Total acidity \% of Williams banana during 2016/2017 and 2017/2018 seasons.

\begin{tabular}{|c|c|c|c|c|c|c|c|c|}
\hline \multirow{2}{*}{$\begin{array}{l}\text { Season } \\
\text { Treatment }\end{array}$} & \multicolumn{4}{|c|}{$2017 / 2016$} & \multicolumn{4}{|c|}{ 2018/2017 } \\
\hline & Zero & (Twice $\mathbf{G A}_{3}$ ) & (thrice $\left.\mathbf{G A}_{3}\right)$ & $\operatorname{Mean}(B)$ & Zero & $\left(\right.$ Twice $\left.\mathbf{G A}_{3}\right)$ & (thrice $\mathbf{G A}_{3}$ ) & Mean(B) \\
\hline Control & 0.372 & 0.357 & 0.339 & 0.356 & 0.368 & 0.352 & 0.335 & 0.352 \\
\hline PB(2g) & 0.310 & 0.297 & 0.283 & 0.297 & 0.314 & 0.291 & 0.286 & 0.297 \\
\hline PB(4g) & 0.315 & 0.303 & 0.278 & 0.299 & 0.310 & 0.298 & 0.283 & 0.297 \\
\hline Mean (A) & 0.332 & 0.319 & 0.300 & & 0.331 & 0.314 & 0.299 & \\
\hline L.S.D 5\% & & $\begin{array}{c}\mathrm{A}= \\
\mathrm{B}= \\
\mathrm{AB}=\end{array}$ & $\begin{array}{l}.015 \\
.011 \\
0.019\end{array}$ & & & $\begin{array}{r}\mathrm{A}= \\
\mathrm{B}= \\
\mathrm{AB}=\end{array}$ & $\begin{array}{l}.012 \\
.010 \\
0.017\end{array}$ & \\
\hline
\end{tabular}

\section{DISCUSSION AND CONCLUSION}

\section{1- Discussion}

Bananas owing to its large size and rapid growth rate require relatively large amounts of $\mathrm{GA}_{3}$ to get high yield with good fruit quality. Gibberellins control fruit development in various ways and at different developmental stages. Fruit development is a complex and tightly regulated process. Gibberellins are known to influence both cell division and cell enlargement (Adams et al., 1975) and (Kamijima, 1981). The results were in agreement with those achieved by Pradhan, et al, (1988), Samra, et al, (1989), Hemeed, (2006) and Ebeed. Sanna et al, (2008).

Application of paclobutrazol on yield with increased size and number fruit on plant caused increased yield on plant. Paclobutrazol caused effects signification on fruit quality with increased of contain T.S.S and decreased TA. (Lolaei et al., 2012 a,b) and (Lolaei et al., 2013). Similar remits reported by authors.

\section{2- Conclusion}

Therefore, it could be concluded that spraying $\mathrm{GA}_{3}$ at $40 \mathrm{ppm}$ thrice at just after emergence of the last hand, one month later); and on $1^{\text {st }}$ week of August, as well as spraying $\mathrm{PB}$ at $2 \mathrm{~g}$ at Aug. to obtain high yield with good fruit quality.

\section{REFERENCES}

Abdel-Moniem-Eman, A., A.S.E. Abd-Allah and M.A. Ahmed (2008). The combined effect of some organic manures, mineral $\mathrm{N}$ fertilizers and Algal cells extract on yield and fruit quality of Williams Banana plants. American Eurasian J. Agric. \& Environ. Sci. 4 (4): 417-426.

Adams P.A, Montague M.J., Tepfer M, Rayle DL. and Ikuma H and P.B. Kaufman (1975). Effect of gibberellic acid on the plasticity and elasticity of Avena stem segments. Plant Physiol.; 56:757-760.

Association of Official Agricultural Chemists (1995). Official Methods of Analysis (A.O.A.C) $14^{\text {th }} \mathrm{Ed}$, Benjamin Franklin Station, Washington, D.C, U.S.A. pp: $490-510$.
Chattopadhyay, P.K. and A.K. Jana,(1988). Effect of growth substances on fruit growth and development of Gaint Governor Cavendish banana (Musa cavendishii L.). Progressive Hort., 20(1-2): 136-139.

Dinesh Kumar and B.M.C. Reddy, (1998). Effect of growth substances on fruit size, yield and quality of banana cv. Neypoovan. Environment and Ecology, 16(4): 937-939.

Duncan, D.B., (1955). Multiple range and multiple "F" tests. Biometrics, 11: 1-42.

Ebeed. S, Mostafa, E.A.M and M.M.S. Salah (2008). Effect of Gibberellic acid and Male Bud Removal on Yield and Fruit Quality of Banana Plants. J. Agric. and Biological Sciences, 4(4): 289-292

FAOSTAT (2016). Food and Agricultural Organization of the United Nations.Data available at $\mathrm{http} / /$ www.fao.org/faostat/en/\#data/QC.

Gomez, K.A. and A.A. Gomez (1984). Statistical Procedures for Agriculture Researches ( $2^{\text {nd }} E d$.) Published by John Wiley and Sons, New York, U.S.A. p. 10-20.

Hemeed, A.A.R., (2006). Effect of Gibberelic acid, active dry yeast and bunch trimming treatments on physical and chemical characteristics of Williams banana fruit. M. Sc. Thesis, Cairo Univ., pp: 237.

Higa, Y. and G.N. Wididana (1991). Changes in the soil micro flora induced by effective microorganisms. Proc. of $1^{\text {st }}$ Inter. Conf. of Kyusei Nature Farming M.S. Dept. of Agric., Washington, D.C. U.S.A., pp. 153-162.

Kamijima O. (1981). Consideration on the mechanism of expression of dwarf genes in rice plants. II. The actions of dwarf genes on cell division and cell elongation in parenchyma of internode. Jap. J. Breed. 1981; 31:302- 315.

Lolaei A, Rezaei MA, Khorrami Raad M. and B. Kaviani (2012). Effect of Paclobutrazol and Sulfate Zinc on Vegetative Growth, Yield and Fruit Quality of Strawberry (Fragaria $\times$ ananassa Duch. cv. Camarosa). Annals of Biological Research, 3 (10):4657-4662. 
Lolaei A., Kaviani B., Khorrami Raad M., Rezaei MA and M. Maghsoudi (2012). Effect of Paclobutrazol and Salinity on Vegetative and Sexual Growth and Fruit Quality of Strawberry (Fragaria $\times$ Ananassa Duch. cv. Selva). Annals of Biological Research, 2012, 3 (10):4663-4667.

Lolaei A., Mobasheri S., Bemana R. and N. Teymori (2013). Role of Paclobutrazol on Vegetative and Sexual Growth of Plants. Intl J Agri Crop Sci. Vol., 5 (9), 958-961, 2013.

Marschner, H.C (1996). Mineral nutrition of higher plant. Academic Press Limited Text Book, $2^{\text {nd }}$ Ed. 868.

Mead, R., R.N. Currnow and A.M. Harted (1993). Statistical Methods in Agricultural Biology. $2^{\text {nd }} \mathrm{Ed}$. Chapman \& Hall, London, pp: 54-60.

Miller, E.W., D.L. Donahue and J.U. Miller (1990): Soils "An Introduction to soils and plant Growth" (5th ed.). Prentice Hall, International Inc. Engleword Cliffs, New Jersy, pp 303- 339.

Moore, T.C., (1979). Biochemistry and physiology of plant hormones. Pub. By Springer-Verlag. New York. USA.

Nijar, G.S. (1985). Nutrition of fruit trees Mrs. Usha Raj Kumar for Kalyanin publishers, New Delhi, p. 1052.
Nolin, J (1985). Stage of maturity of banana (cv. Giant Cavendish) at harvest a new measuring method. Fruits, 40 (10): 623-631.

Pradhan, S.K., A. Bandyopadyay; S.K. Mitra and S.K. Sen, (1988). Effect of growth substances on fruit size, yield and quality of banana var. Giant Governor. Progressive Hort., 20(3-4): 326-330.

Saleh, M.M.S. (2001). Effect of different nitrogen fertilizer forms on growth, mineral content and yield of banana plants. Arab Universities J. of Agric. Sciences, 9 (1):355 - 371.

Samra, N.R., M.I. El-Kady and A.S. Hossam El-Deen, (1989). Effect of malee bud removal and GA treatments on yield and fruit quality of banana fruits. J. Agric. Sci. Mansoura Univ., 14(2): 1206-1213.

Suman,Mahaveer, Pency D Sangma, Deva Ram Meghawal and Om Prakash Sahu. (2017). Effect of plant growth regulators on fruit crops. Journal of Pharmacognosy and Phytochemistry 2017; 6(2): 331-337

Tadros, M.R., A.S. Khalifa, A.Z. Bondok and M.B. Bastawros, (1984). Effect of GA application on the growth of banana bunches. Annals Agric. Sci., 29(1): 485-492.

Yagodin, B.A (1990). Agriculture Chemistry. Mir Publishers Moscow, p. 278-281.

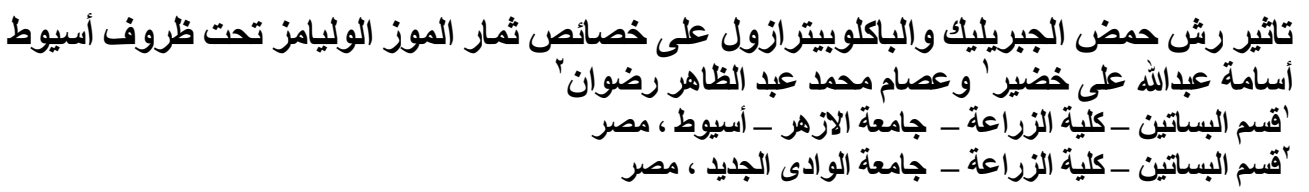

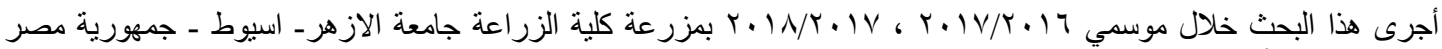

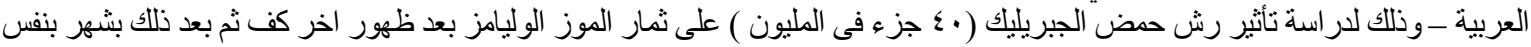

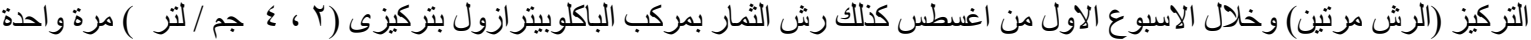

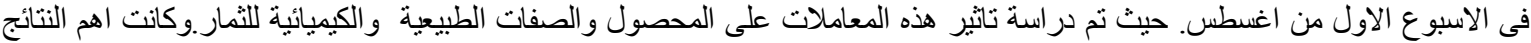

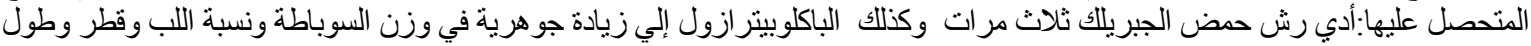

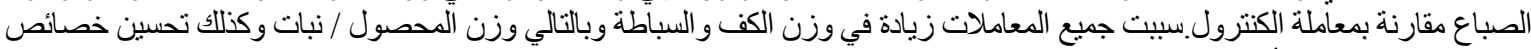

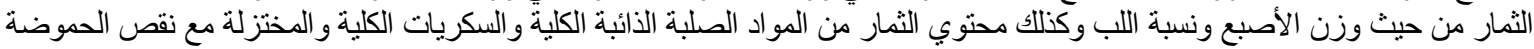

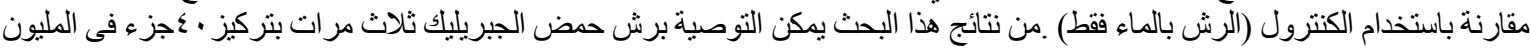
و الباكلوبيتر ازول r جر ام/لتر على سوباطات الموز الوليامز للاسر اع من اكتمال نمو الثمار و إنتاج محصول عال ذأل ذو خصائص ثمرية جيدة. 